\title{
Environmental Imagination and Wonder in Beatrix Potter
}

\author{
Lorraine Kerslake
}

\begin{abstract}
Drawing inspiration from Rachel Carson's paper 'Help your Child to Wonder' (1956) and Lawrence Buell's seminal term "environmental imagination" (1995) referring to the reader's ability to experience a sense of connection with the environment and a deeper understanding and appreciation of the natural world, this chapter looks at the role that children's literature can play in imagining a more sustainable society and the importance of instilling a sense of wonder to the natural world in children. In order to question the role and power of children's literature it highlights the contributions of Beatrix Potter to the study, protection and writing of nature and looks at Potter's own literary ecology, including her engagement with nature and the sources of her inspiration. By focusing on the figure of Potter and showing how her own engagement with the natural world formed the children's tales she wrote and illustrated, this paper raises key issues for ongoing debates within ecocriticism and environmental humanities such as Potter's use of anthropomorphism and the role of imagination in bringing about change.
\end{abstract}

\section{Keywords}

Beatrix Potter; animals; ecocriticism; Rachel Carson; sense of wonder; imagination

If I had influence with the good fairy who is supposed to preside over the christening of all children, I should ask that her gift to each child in the world be a sense of wonder so indestructible that it would last throughout life, as an unfailing antidote against the boredom and disenchantment of later years, the sterile preoccupation with things that are artificial, the alienation from the sources of our strength.

RACHEL CARSON, The Sense of Wonder 54

(C) LORRAINE KERSLAKE, 2022 | DOI:10.1163/9789004501270_006

This is an open access chapter distributed under the terms of the CC BY-NC 4.0license e Kers lake - 9789004501270 
In today's environmental crisis environmental humanities and ecocriticism offer critics, ${ }^{1}$ writers and educators a framework with which to recover the importance of the natural world in literature and provide a more holistic view to human's relationship to nature. In this context, the way humans behave is shaped largely by cultural values, including the stories that make up our childhood imagination. As Rachel Carson put forth, the path to building an ecological consciousness lies in responding to the awe of nature expressed by children.

Drawing inspiration from Rachel Carson's paper 'Help your Child to Wonder' (1956), ${ }^{2}$ and Lawrence Buell's seminal term 'environmental imagination,' ${ }^{3}$ referring to the reader's ability to experience a sense of connection with the environment and a deeper understanding and appreciation of the natural world, this chapter looks at the role that children's literature can play in imagining a more sustainable society and the importance of instilling that sense of wonder to the natural world in children. In order to question the role and power of children's literature it draws on Beatrix Potter's life and works and looks at how Potter's literary ecology shaped her attitude to the more-than-human world and asks whether her work might still instill wonder in children today.

Potter's literary ecology (her engagement with nature, the sources of her inspiration, and her political commitment with the conservation and protection of the environment) are at the roots of today's ecocritical theory. Taking Cheryll Glotfelty's definition of ecocriticism as "the study of the relationship between literature and the physical environment" (Glotfelty xviii) where ecocriticism "takes as its subject the interconnections between nature and culture, specifically the cultural artifacts of language and literature" (xix), children's literature would appear to be an ideal domain to explore the intersections of social sphere, nature and imagination.

Given that environmental education begins during the early years of childhood, the stories that we read as children influence the way we respect and value nature later in our lives. In today's society, where children are becoming increasingly detached from nature, children's literature is a powerful means of reconnecting younger generations with the more-than-human world by

1 This work was supported by Proyectos I+D+I Grupos De Investigación Emergentes, Conselleria de Innovación, Universidades, Ciencia y Sociedad Digital, Generalitat Valenciana. Grant Number GV /2020/029.

2 The essay, which was first published in Woman's Home Companion, in 1956, was later published posthumously as The Sense of Wonder (1965).

3 Buell's term comes from his book The Environmental Imagination: Thoreau. Nature Writing and the Formation of American Culture (1995). 
creating a sense of wonder. This puts children's writers in a position of singular responsibility, for it is largely up to them to transmit not only cultural values, but to educate and teach respect for our natural world. Children's literature has long proved a hospitable habitat for non-human animals, and the intersections between nature and culture and our relationship with animals have long preoccupied children's authors. Environmental criticism and children's literature often share the concern of environmental imagination (sense of place, affinity to animals, etc.) which has its roots in what we read as children.

In their introduction to Wild Things Dobrin and Kidd affirm that "it is critical to recognize that any ecocritical look at children's literature must include ecofeminist perspectives" (10). Indeed, ecofeminism's concern with the domination of nature and mistreatment of animals, parallel to that of people, also takes into account that whilst human imagination reconnects us to animals, we still tend to see them as the Other, highlighting the need to address the questioning of what it means to be human alongside that of other beings in David Abram's 'more-than-human world'. ${ }^{4}$ In words of Abram "our obliviousness to non-human nature" (28) stems from our profound anthropocentricism. Like Carson, Abram brings to light the importance of awakening our senses and suggests that there is a synergistic relation between the human and nonhuman which begins in childhood but usually fades in adulthood through our alienation with nature.

In this context, an ecofeminist reading of Potter's life and work may offer new insights. As Marion Copeland (2004) has commented Potter experienced enough repression Potter experienced enough repression as a woman naturalist to "be drawn to ecofeminism's linking of the oppression of women and the domination of nature" (Copeland 71). Indeed, Potter's own story and her scientific study of mycology show how, throughout history, Western society has systematically shut out female writers from nature sciences. As Carolyn Merchant in The Death of Nature: Women, Ecology, and the Scientific Revolution (1980), explains destructive attitudes towards women and nature stem from the emergence of modern science and seventeenth century's scientific revolution which came at the expense of women rights and the environment.

Potter was in fact only one of many pioneering women who crusaded during the Victorian and Edwardian Age to preserve and protect nature and revise evolutionary ideas about the relationships between humans and other animals.

4 Abram coined the phrase 'the more-than-human world' as a way of referring to earthly nature and is used as the subtitle of his book The Spell of the Sensuous: Perception and Language in a More-than-Human World (1996). Since then the term has been largely adopted by other scholars and has become a key phrase within ecopsychology and ecocriticism. 
Potter's early interest in natural sciences and the reasons why she abandoned her studies in mycology have often been overlooked by critics. For Potter did a lot more than draw the natural world. Not only did she draw with meticulous observation over three hundred and fifty illustrations of fungi but she also grew various fungal spores. She was the first person in Britain to speculate in a scientific paper that lichens are symbiotic life forms, and recorded in detail her observations of algal and fungal properties. In April 1897 and after careful preparation, Potter was ready to present her paper 'Germination of the spores of the Agaricineae' to the Linnean Society of London. However, as Kerslake argues (81), the male botanists at Kew Gardens were both sceptical and reluctant to listen to a woman's theory on how fungi spores reproduced. Her paper was offered to the Linnean Society through a botanist at Kew Gardens, George Massee, a member of the Society, but her theories were not taken seriously, and the paper was not recommended for publication.

Undoubtedly if Beatrix Potter had been born a man or a century later, she would have been remembered as a well-known naturalist, but in her time her observational skills in natural history and her artistic talents in mycology were not taken seriously. Luckily for her readers, it was this lack of scientific recognition that made her leave her studies in fungi and turn instead to her animals for inspiration, firstly by illustrating books and making cards and later by writing and illustrating her own little tales. She was, in words of Barbara Gates, "especially well equipped for this enterprise" since "From an early age, she knew her animals as she would come to know her fungi- from a scientific perspective" (231).

Potter was born into a wealthy middle-class Victorian family and lived in Bolton Gardens, Kensington. She was educated at home where she studied books and painting and was looked after by her nanny, together with her younger brother Bertram, until he went to school. She did not socialize with other children and saw her parents at bedtimes and on special occasions. Having little company, she turned to nature from an early age, fascinated by animals, fossils and plants, which she spent hours drawing and immortalising.

Although this aspect of her confined childhood and her apparently tyrannical parents have often thought to be responsible for her solitary nature, given the period and class in which she had been born her restrictive upbringing was similar to that of other children of her age. Given that from the age of five she was allowed to keep her own menagerie including rabbits, lizards, mice, newts, guinea pigs, a hedgehog and snails in her nursery, suggests that it was actually far more progressive than many of her contemporaries.

Both her lonely childhood and self-education influenced her art and work. As a child, much of her inspiration came from her frequent visits to both Kew 
Gardens and Kensington Gardens, as well as to the Natural History Museum and the South Kensington Museum (later the Victoria and Albert Museum) where she would quietly observe and draw her first sketches and scientific drawings. In her journal, dated Dec 20, 1895, she describes one of her outings there: "Went to the Museum, very empty and quiet. Studied fossils peaceably, and afterwards the insects again, but investments and a general twitch got too much for me. I never saw anything so fearful as the stuffed animals; I had not been in that gallery for a long time till the other day" (Linder 412). Potter's careful observations and feeling of awe point to her early sense of empathy with nature and the non-human. Her engagement with the Other, informed by her stewardship of animals throughout her life and work, is shown as a bond of respect which she portrayed from an early age. She was both an acute observer and a detached scientist; her major concern was to remain as accurate and faithful to the true nature of animals as possible. Her awareness of this allowed her a privileged understanding of animal behaviour from a different angle from other children's book illustrators and writers of the Golden Age who offered a more sentimentalized view of nature. Furthermore, in the case of Potter, text and illustration are equal components in each of her evocative tales.

As Kerslake argues, part of her artistic talent was inherited from her father who was an amateur photographer as well as close friends to artists such as the Pre-Raphaelite John Millais (82). From an early age she grew up surrounded by art and books; her first encounters with Edward Lear were at the age of four, followed by John Tenniel's Alice Adventures in Wonderland. She grew up with Aesop's fables and Scottish folk tales as well as Grimm and Andersen's fairy tales. She read the Old Testament, Shakespeare, Swift as well as her contemporaries Lewis Carroll, Charles Kingsley and Edward Lear and was greatly influenced by the picture books of Walter Crane, Kate Greenaway and Randolph Caldecott. However, as Anne Stevenson Hobbs has noted, "she surpasses her contemporaries in the careful accuracy of her observation, and in her questioning, analytical approach." (23). Potter was, both in her art and writing, basically herself. In her journal entry on October 4 th 1884 , she comments about her own humble attitude to art: "It is all the same, drawing, painting, modelling, the irresistible desire to copy any beautiful object that strikes the eye. Why cannot one be content to look at it? I cannot rest, I must draw, however poor the result" (in Linder 109).

As a young child Potter's drawing books already showed her artistic talent. All the plants, insects and other creatures Bertram and her brought home soon became models for Potter's fine eye for detail. At nine Potter was already writing about the feeding habits of her caterpillars in her journal. She also studied the breathing system of her newts and frogs and kept records of the hibernation 
patterns of her hedgehog together with specific details of her rabbits' behaviour. Periodically she would measure each of her animals, carefully keeping record in her notebook. Her own pets were of course models for the inspiration behind many of the characters in her books. Amongst her favourites were her rabbits, especially Benjamin H. Bouncer, who she had before Peter, her mice, and her hedgehogs. Amongst her lizards, dogs, cats, horses, hens, sheep, pigs, guinea pigs, mice, frogs, birds and other beasts, she named over go different 'pets'. When they died, she would sometimes boil off the skin and flesh to study and sketch their bones, or stuff them, with the help or guidance of her brother Bertram. She once wrote to her brother, somewhat concerned about his pet bat as it was not eating. His reply gave her specific instructions on how to proceed.

\section{Dear B,}

I am sorry to hear your news of the bat. If he cannot be kept alive, as I suppose he can't, you had better kill him, and stuff him as well as you can. Be sure to take his measurements most carefully before you stuff him.' (Letter from Bertram Potter, Oct 12th, 1884) ${ }^{5}$

The young Beatrix Potter obediently carried out his somewhat gruesome request to painstakingly dissect and stuff the bat and then proceeded to draw him as accurately as possible, with the same scientific detachment and mastery that can be found in her little tales. Graham Greene correctly described Potter as "an acute and unromantic observer, who never sacrifices truth for an effective gesture" (232).

As Kerslake has observed (85) her own relationship with animals show that they are both like and at the same time not like us. Her attitude to nature lacked any sentimentality or sense of squeamishness, and this same matter-offact quality can be seen in her own little tales. The Tale of Peter Rabbit (1902) begins with a horrifying image of Peter's father's death. When Peter's mother warns Peter and his sisters not to go to Mr. McGregor's garden the reason she candidly gives them is that their "Father had an accident there; he was put into a pie by Mrs. McGregor" (9). ${ }^{6}$ This transition of happenings is shown in Potter's first edition with an illustration of a young child at the table and a dog drooling whilst Mrs. McGregor presumably serves the pie in which Peter's father had been baked. Much to Potter's dismay Warne insisted on the image being too explicit and frightening for young readers and removed it from the

5 Quoted her in Beatrix Potter: A Journal. (London: Frederick Warne, 2011), p. 6.

6 All references are from Beatrix Potter: The Complete Tales (2002). 
1902 edition. This opposition between nature and culture together with Potter's own no-nonsense attitude is present at many levels in Potter's tales.

In Potter's art the intertwining of human and animal nature often becomes blurred, creating a sense of oneness. One of the reasons why Potter's anthropomorphic representations are so effective is because of the elements of dark humour and sophisticated irony which often appear embedded in her tales. Young children are often amused by Potter's work because of the fact that rules are broken. Peter, like the disobedient child from moralizing texts of nineteenth-century children's literature, is a familiar figure used to exhort the reader to good behaviour. Except that, in Potter's case, the narrator is on Peter's side. Peter escapes from danger and later drinks chamomile tea from the warmth of his bed. The circular womb-like form of the burrow suggests that he has returned safely to home. Peter's escapism suggests that children should be allowed to explore, play outside and get dirty, contradicting Victorian social restrictions and conventions, anticipating Carson's sense of wonder and the importance of discovering nature. Children know that rabbits don't wear waistcoats but can easily identify with her characters and take pleasure in her sardonic humour which favours Peter at the expense of his wellbehaved sisters. Despite the fact she rarely depicts human beings in her tales, her dressed-up creatures reveal as much about human virtues and handicaps as about the natural world.

The popularity of Potter's tales has endured not because the world she depicts is comforting and idyllic as her twee illustrations may at first mislead us to perceive, but because of what lies underneath the surface. Indeed, amongst the more controversial aspects of Potter's anthropomorphism is the need to get past what lies on the surface of her work including the subtle change of size and the metaphor of clothing as well as the smoke-screen of human/animal behaviour, when her animal characters display human actions and act as mirrors or models of human behaviour.

Many of her animals appear both wearing clothes or in their natural state. They act like real animals when they appear naked and become personified and mirror human behaviour when they are dressed. It is Peter's clothing that almost prevents him from escaping from Mr. McGregor's garden. Like Adam and Eve after losing their innocence in the garden of Eden, when Peter loses his shoes in Mr McGregor's garden, he becomes more animal. For Peter, the transition from being clothed to his real animal nature takes place when he loses his clothes and is able to escape.

Although not all of Potter's characters appear dressed, those that are usually wear elegant but uncomfortable clothes that prevent them from walking naturally or do not fit properly. Clothes are usually constricting and symbolise 
tension, parallel to the attitudes concerning social conventions and the decorum of upper and middle-class Victorians. In The Tale of Tom Kitten (1907), as Ruth MacDonald has noted, Tom is dressed in clothes that "make the kitten look like a cross between Little Lord Fauntleroy and Tom Sawyer on his way to church" (100). However, not only do the buttons on Tom's coat burst, and his clothes get dirty, but his sisters also fail to conform to civilized human behaviour by losing their outfits too. When they all return home naked, Tom's mother, Tabitha, locks them upstairs in an attempt to hide them from her guests, explaining that they have measles.

As if to reflect the contradictions inherent in animals wearing clothes, Potter's scenes are simultaneously domestic and disturbing, portraying familiar settings such as having afternoon tea, where one might at the same time find themselves becoming a banquet for others. However, Potter's animals appear at their most disturbing when they act like people.

One of these more grotesque moments that Potter carefully entwines in her tale appears in the sequel to Tom Kitten's story, The Tale of Samuel Whiskers (1908), first published as The Roly-Poly Pudding (1908). Already at the very beginning of the story, Tabitha Twitchit, Tom Kitten's mother, tells very matterof-factly, in a sardonic reverse to that of Peter Rabbit's mother, how she caught seven young rats "out of one hole in the back kitchen, and we had them for dinner last Saturday" (179). Potter had recently acquired Hill Top Farm in the Lake District, thanks to the profits of her books and, much like Tabitha, found the old farm overrun with rats when she first moved in. In the tale Tabitha decides to lock Tom, along with his two sisters Moppet and Mittens, in a cupboard to keep them under control. However, Tom escapes up the chimney, only to find himself with Samuel Whiskers, a mean old rat, who gives directions to his wife, Anna Maria, to make him a "kitten dumpling roly-poly pudding" (187) for his dinner. From this scene Potter's illustration contains a gruesome underlying tone. Anna Maria rushes upon poor frightened Tom, with a menacing look, rolling and tying him up with string. Whilst Tom Kitten has lost his jacket and appears without clothes, both Anna Maria and Samuel Whiskers remain fully dressed. Anna Maria then goes to the kitchen to steal the dough, leaving Tom under the floor of the attic.

Potter then presents a black and white image of Tom, facing away from the audience with his head towards the wall, bound by his paws. However, an even more disturbing coloured illustration follows depicting the poor kitten lying on his back, head back and mouth gagged with his paws bound tightly to his body. Potter then elaborately informs us of how the rats "set to work to make him into a dumpling with a rolling pin" (190). Her own sardonic brushstroke 
comes when Samuel Whiskers then asks with some concern "Will not the strings be very indigestible, Anna Maria?" (190).

Thanks to the noise, that attracts Tom's mother, the rats are discovered, and Tom is rescued and safely returned home. Potter ends the tale by conjuring in the reader's mind more gruesome images, in this case of rats' tails hanging on the barn door, with the following words: "Moppet and Mittens have grown into very good rat-catchers. [...] and earn their living very comfortably" (195).

In a similar way to Mrs McGregor's pie in The Tale of Peter Rabbit, in other tales, other animals serve as food for both predators and humans. In The Tale of Jemima Puddleduck (1908) an elegant Mr Tod deceives the naïve duck to the point that not only does she agree to come to his dinner party but she also promises to bring "Sage and thyme, and mint and two onions, and some parsely" (167) for the stuffing. She manages to escape thanks to Kep, the collie dog and two fox-hound puppies who rescue her. Like the cat and birds that appear in The Tale of Peter Rabbit the dogs are not dressed, nor do they have the ability to speak but instead bark and behave like dogs do. So much to the point that the irony of the tale resides in the fact that the puppies end up eating Jemima's eggs.

Together with her underlying irony Potter's satirical eye offers a critical attitude towards the excessive materialism and snobbery of her time, criticising Victorian consumerism. The Tale of Mr Jeremy Fisher (1906), mocks artificial emphasis on manners. In the tale, Mr Jeremy Fisher first appears very much as a humanised gentleman frog of leisure portraying the blurring between animals dressed up in human clothing. He is first portrayed sitting outside reading the newspaper with his white socks and small delicate pumps that ironically serve to disguise his webbed feet. Jeremy is a predator himself to smaller animals: his lunch consists of a "butterfly sandwich" (124), whilst for dinner he invites his friends to enjoy "roasted grasshopper with ladybird sauce" (130). However, as Daphne Kutzer notes "if Jeremy is a gentleman he is somewhat out of his depth in the wider world of the pond, a world that contains wild creatures that pose an immediate threat to his obliviously happy, upper-class life" (119). The first of these threats is a water beetle which "came up underneath the lily leaf and tweaked the toe of one of his galoshes" (125), followed by the rustling sound of water rats in the reeves which Potter illustrates, like the beetle and other predators, without clothes and with scientific accuracy. As Kerslake argues (88) the irony of the tale is that it is thanks to his mackintosh, and his denial of his animal nature, that Jeremy is saved: "the trout was so displeased with the taste of the macintosh that in less than half a minute it spat him out again" (127). 
However, despite these more controversial aspects Potter's stories are, in general terms, more inclined to naturalism since her creatures are real ones, not just people in disguise. In this sense all her animals have real dwellings: Jeremy Fisher lives by a pond, Peter Rabbit and his family live in a sandbank as rabbits do, although the den has a sink and reminds us of a human home. Other animals that coexist with humans live in human dwellings: Jemima Puddleduck lives on a farm whilst Tabitha Twitchit and her kittens live in an old Victorian house, ridden with mice. Moreover, their animal behaviour is exactly what we would expect: frogs live in ponds and like to get wet, mice make holes and gnaw at things, rabbits sneak into gardens and eat vegetables, cats scratch and play. Their animal homes are safe whilst the human outside world is full of dangers. But of course, as in the case of Peter Rabbit, they often prefer to go outside their own natural boundaries and come into conflict with the human world.

In The Tale of Two Bad Mice (1904), its main characters end up destroying the upper-middle-class Edwardian doll's house where they find everything for show but not for use. The dolls' lives are an illusion of the bourgeois society they live in and reflect Potter's critique of Victorian false appearances and Edwardian excess. However, read in the light of materialism and the insatiable consumerist society in which we live, much of it still rings true. The tale reflects not only Potter's desire to leave home but her own fears and frustrations about domesticity and independence. As Kutzer correctly observes, in the tale we can see Potter's "absolute delight in bringing disruption, destruction, and energy into a house as stifling and life-denying to the dolls and mice as Bolton Gardens was to her" (71). Written at a time when she was caught in her own difficulties of rebelling against her parents and her wish for independence, the tale reads largely as a reflection of Potter's own domestic upbringing and her family's constraints. At its time of publication, Potter, who was approaching forty, was already making a living from her little books, making it possible for her in theory to leave her parent's home, although of course to have done so would have violated her parent's rules and the Victorian norms of female propriety.

1905 was an important year for Beatrix Potter. She decided to buy a farm called Hill Top in the Lake District, near Sawrey. That same year, during the summer, her publisher, Norman Warne, asked her to marry him. Her parents were appalled, since the son of a publisher was considered an unsuitable match for the daughter of a barrister. Potter had argued with her parents about accepting the proposal of marriage, and finally decided not to announce their engagement. However, only weeks later her hopes were cruelly shattered when Warne fell ill and died suddenly of leukaemia at the end of August. Potter was 
devastated and took to burying herself in her tales. Consequently, the period that followed was her most prolific.

In 1909 she bought Castle Farm, near Sawrey. In 1913, at the age of 47, she married her solicitor William Heelis and moved into Castle Cottage. That same year she published The Tale of Pigling Bland (1913), a tale about a pig who finds love and dances "over the hills and far away" (308), symbolising her own escape to a new life. As Humphrey Carpenter writes it reflected Potter's "exhilaration at her own personal escape, in the year that it was published, from the family fold, and the freedom that her marriage granted her" (296). As Mrs Heelis, Potter was known not as a writer but as a Lake District farmer and sheep breeder. With her profits she bought more estates and farms. In her will she left over 4,ooo acres of land, including Hill Top, to the National Trust, so as to preserve the beauty of its countryside. She sought both in life and art to influence her readers to conserve the borderlands and farmlands of the English countryside.

Potter's real aspiration is often overlooked perhaps because it is so obvious and yet so simple as she has put in her own words in her diary in February 1909: "I have always tried to show unspoilt nature in my books. If I have done anything, even a little, to help small children enjoy honest, simple pleasures, I have done a bit of good" (in Lear 309). ${ }^{7}$ Like Carson, she sought to influence her young readers to conserve the beauty of their local countryside. Both women shared a similar concern to portray the beauty of nature so that the child's 'sense of wonder' would not fade in adulthood. Potter was happiest not as a writer but later in her life as a farmer in the Lake District when she was actively engaged with nature.

From an ecocritical point of view, as Lawrence Buell (1995) has suggested empathy is key to the development of an environmental ethic. Potter's tales show a clear sense of empathy towards nature, but, as Kerslake observes, despite the fact that she created Arcadian, idyllic landscapes "there is nothing romantic about her tales, for her aim was not to elicit sentimentality in her readers. Her anthropomorphism does not seek an emotional response nor does she foster compassion towards animals, instead she shows respect and encourages coexistence" (90). Potter's tales portray nature as it is for as Margaret Blount reminds us, "Animal life is not happy in the human sense; it is merely neutral [...]. Giving these small animals human qualities is to put them out of reach of inevitable fear, pain and death which is their natural lot" (131). In Potter's little tales' nature is, more often than not, "red in tooth and claw", as

7 Original quote comes from a letter Potter wrote to her friend Kitty Holdsworth, 5 July 1928. 
Tennyson puts it, and for the likes of Peter Rabbit, Tom Kitten or Jeremy Fisher, the moral is simply how not to get eaten.

The term of Anotherness, as applied to ecocriticism by Patrick Murphy (2006), is also relevant in Potter: the recognition of the Other as a self-existing entity that is respected, rather than exploited. Otherness is always out of reach. The engagement with the other is shown as a bond of respect, although at times this can cause friction. Take Peter Rabbit and the garden. Peter violates the rules of the garden. Not only does he trespass, by entering the garden, but he steals and eats Mr McGregor's vegetables. The natural balance is altered, but in the end harmony reigns. Potter's way of thinking about human-animal relations and her handling of tension and discomfort reflects themes which can raise awareness of a need for change in the reader on both an emotional and imaginative level.

The roots of environmental imagination lie in the experience that we envision through children's literature in our childhood. The books that we read as children come to be a part of us and shape who we become, influencing the way we respect and value nature later in our lives, for it is in those years of wonder when the child's innate curiosity for the environment is shaped. Potter's unique vision as both a scientist and an artist together with her environmental understanding to preserve nature gave her a special touch that few other writers have conceived. The combination of knowledge, imagination, art and science in Potter's tales fosters respect and care towards the more-than-human world.

By engaging children's literature with our imagination Potter touches on the ongoing debate within environmental humanities about the role of imagination as a key agent in bringing about change and a way to influence our sense of environmental ethics. By instilling in her readers a sense of wonder Potter offers a deeper understanding and appreciation of the natural world.

Despite the fact that Potter's tales are deeply Victorian, they can still awaken the imagination of children in today's society, a society where younger generations are becoming increasingly more divorced from nature. ${ }^{8}$ Inspired by Carson and the idea that adults can and should help children discover and enjoy nature, Richard Louv (2005) coined the term 'nature-deficit disorder'9 to refer to how children (and adults alike) are becoming more alienated from the natural world and to warn of the future consequences this would have.

Questioning where we are today in our understanding about the sense of wonder in young children, both Potter and Carson urge us to use all our senses

8 In 2012, a National Trust report called Natural Childhood revealed the growing gap between children and nature. In 2013, the RSPB published a study which concluded that four out of five children in the UK were not adequately 'connected to nature'.

9 See Louv, Last Child in the Woods: Saving our Children from Nature Deficit Disorder (2005). 
and explore nature with our feelings and emotions. Anticipating Buell, Potter's tales also put forth the claim that today's environmental crisis "involves a crisis of the imagination the amelioration of which depends on finding better ways of imagining nature and humanity's relation to it" (Buell 2).

In this context, perhaps her tales can help us find ways to strengthen that imagination in today's society and attempt to bring about change. Herein Potter's more-than-human world lies hope.

\section{Works Cited}

Abram, David. The Spell of the Sensuous. Vintage, 1996.

Blount, Margaret. Animal Land: The Creatures of Children's Fiction. Avon-Hearst, 1977.

Buell, Lawrence. The Environmental Imagination: Thoreau. Nature Writing and the Formation of American Culture. Harvard UP, 1995.

Carpenter, Humphrey. "Excessively Impertinent Bunnies: The Subversive Element in Beatrix Potter." Children and Their Books: A Celebration of the Work of Iona and Peter Opie, edited by Gillian Avery and Julia Briggs, Clarendon, 1989, pp. 271-98.

Carson, Rachel. The Sense of Wonder. Harper and Collins, (1965); 1998.

Copeland, Marion. "The Wild and Wild Animal Characters in the Ecofeminist Novels of Beatrix Potter and Gene Stratton-Porter." Wild Things: Children's Culture and Ecocriticism, edited by Sidney I. Dobrin and Kenneth B. Kidd, Wayne State UP, 2004, pp. $71-81$.

Gates, Barbara. Kindred Nature: Victorian and Edwardian Women Embrace the Living World. U of Chicago P, 1998.

Dobrin, Sidney I., and Kenneth B. Kidd, editors. Wild Things: Children's Culture and Ecocriticism. Wayne State UP, 2004.

Glotfelty, Cheryll. "Introduction: Literary Studies in an Age of Environmental Crisis." The Ecocriticism Reader: Landmarks in Literary Ecology, edited by Cheryll Glotfelty and Harold Fromm, U of Georgia P, 1996, pp. xv-xxxvii.

Greene, Graham. "Beatrix Potter." Collected Essays. Bodley Head, 1969, pp. 232-40.

Kerslake, Lorraine. "Of Mice, Rabbits and Other Companion Species in Beatrix Potter's More than Human World" in Reading Cats and Dogs: Companion Animals in World Literature, edited by Slovic, Scott, Françoise Besson, Zélia Bora, and Marianne Marroum: Lexington Books, 2021, pp. 79-93.

Hobbs, Anne Stevenson. Beatrix Potter: Artist and Illustrator. Frederick Warne, 2005.

Kutzer, M. Daphne. Beatrix Potter: Writing in Code. Routledge, 2003.

Lear, Linda. Beatrix Potter: A Life in Nature. St. Martin's, 2007.

Linder, Leslie, editor. The Journal of Beatrix Potter 1881-1897. Frederick Warne, 1989.

Louv, Richard, Last Child in the Woods: Saving Our Children from Nature-Deficit Disorder. Alqonquin, 2005. 
MacDonald, Ruth. Beatrix Potter. Twayne, 1986.

Merchant, Carolyn. The Death of Nature: Women, Ecology, and the Scientific Revolution. Harper and Row, 1980.

Murphy, Patrick. "Grounding Anotherness and Answerability through Allonational Ecoliterature Formations." Nature in Literary and Cultural Studies: Transatlantic Conversations on Ecocriticism, edited by Catrin Gersdorf and Sylvia Mayer, Rodopi, 2006, pp. 417-34.

Potter, Beatrix. Beatrix Potter: The Complete Tales. Frederick Warne, 2002. 